${ }^{1}$ Laboratory of Molecular Cytogenetics, Department of Ruminant Science, Agricultural University of Szczecin, Judyma 10 ,
71-460 Szczecin, Poland
${ }^{2}$ Laboratory of Ruminant Improvement, Department of Ruminant Science, Agricultural University of Szczecin, Judyma 10,
71-460 Szczecin, Poland

SŁAWOMIR ZYCH ${ }^{1}$, MAŁGORZATA SZEWCZUK ${ }^{2}$, EWA CZERNIAWSKA-PIĄTKOWSKA ${ }^{2}$ and IWONA SZATKOWSKA ${ }^{1}$

\title{
A new ACRS-SNP in the 5' flanking region of the bovine insulin-like growth factor 1 (IGF1) gene (Brief report)
}

(Neuer ACRS-SNP in der 5' flankierenden Region des Rindergens für insulinähnlichen Wachstumfaktor 1)

Background: A number of polymorphisms within the bovine insulin-like growth factor 1 (IGF1) gene were described at this time. One of these mutations, a low polymorphic $(\mathrm{CA})_{\mathrm{n}}$ microsatellite in the 5' flanking region of the gene, has been reported by KIRKPATRICK (1992). A T $>C$ transition was identified in the P1 promoter region of the bovine IGF1 gene (GenBank Acc. No. AF017143; GE et al., 2001). LIEN et al. (2000) identified a 4-bp deletion (TTTG) and nine point mutations within non-coding regions of the gene (GenBank Acc. No. AF210383-387). In our study, the sequencing of (CA)n microsatellite fragment revealed another single nucleotide polymorphism (SNP) in the 5' flanking region of the bovine IGF1 gene. The DNA sequence has been deposited to GenBank under accession number DQ975234.

Procedures: The Amplification Created Restriction Sites - Polymerase Chain Reaction (ACRS-PCR) primers were designed using WebCutter ver. 2.0. Primer IgfP1R, with A instead $\mathrm{T}$ at the 3 ' end of the primer, was designed to introduce a TasI recognition site.

\section{IgfP1F 5’ TCATCCAGCTGAGAGATTTGAAT 3’} IgfP1R 5’ TGTGTGTGTGTGTGTGTGTGÄAT 3’

Genomic DNA was isolated from 148 Holstein-Friesian cows using MasterPure ${ }^{\mathrm{TM}}$ Genomic DNA Purification Kit for Blood (Epicentre Technologies/AKOR, Poland). PCR amplification (20 $\mu \mathrm{L}$ final volume) was performed using $2 \mu \mathrm{L}$ of genomic DNA (80 ng), $2 \mu \mathrm{L}$ dNTP mix (2 mM), $1.4 \mu \mathrm{L}^{\mathrm{MgCl}_{2}}(25 \mathrm{mM}), 0.1 \mu \mathrm{L}$ each primer $(100 \mu \mathrm{M}$; IBB PAN, Warsaw, Poland), 0.5 units Taq polymerase (1U/ $\mu \mathrm{L}$; Fermentas/ABO, Gdansk, Poland) and $2 \mu \mathrm{L} 10 \times$ PCR buffer. Thermal cycling began with an initial denaturation step of $94^{\circ} \mathrm{C}$ for $5 \mathrm{~min}$, followed by 33 cycles of $94^{\circ} \mathrm{C}$ for $45 \mathrm{~s}, 58^{\circ} \mathrm{C}$ for $60 \mathrm{~s}, 72^{\circ} \mathrm{C}$ for 50 $\mathrm{s}$, and concluded with a final extension at $72^{\circ} \mathrm{C}$ for $7 \mathrm{~min}$. The SNP was genotyped by TasI digestion of PCR products at $65^{\circ} \mathrm{C}$ for 3 h (recognition site: $\downarrow$ AATT; MBI Fermentas/ABO, Gdansk, Poland). This was followed by electrophoresis in a $2 \%$ agarose gel stained with ethidium bromide to visualize the restriction fragments. The digested 146 
bp PCR product revealed two alleles with fragment sizes 122 and 24 bp for allele $I G F 1^{\mathrm{A}}$; for allele $I G F 1^{\mathrm{C}}$ fragment size was $146 \mathrm{bp}$ (not digested).

Results: In some microsatellites, the repeat units are interrupted by nonrepeat sequences, producing imperfect microsatellites. Occurrence of the "AATA interrupt" in the IGF1 microsatellite was investigated in a number of Artiodactyl species by SHARIFLOU and MORAN (2000). A base substitution polymorphism (A>C transversion) was observed at position of 193 (GenBank accession number DQ975234), within an "AATA interrupt" of the (CA) $)_{\mathrm{n}}$ microsatellite in the 5' flanking region of the bovine IGF1. Frequencies for the $I G F 1^{\mathrm{A}}$ and $I G F 1^{\mathrm{C}}$ alleles were 0.841 and 0.159 , respectively. Frequencies for the $A A$ $(\mathrm{n}=107), A C(\mathrm{n}=35)$ and $C C(\mathrm{n}=6)$ genotypes were $0.723,0.236$ and 0.041 , respectively. The IGF1 gene is expressed as class 1 and class 2 IGF1 mRNA variants in cattle (derived from the P1 and P2 promoters, respectively). Both classes are expressed in a variety of tissues (including muscle and mammary gland) with varying levels (WANG et al., 2003). The dinucleotide (CA) repeat polymorphism located in the 5' region is closely linked to regulatory elements of the P1 promoter. The identification of favourable QTLs that are significantly correlated with genetic merits for meat and milk production traits could lead to more effective selection programs.

\section{References}

GE, W.; DAVIS, M.E.; HINES, H.C.; IRVIN, K.M., SIMMEN, R.C.M.:

Association of genetic marker with blood serum insulin-like growth factor-I concentration and growth traits in Angus cattle. J. Anim. Sci., 79 (2001), 1757-1762

KIRKPATRICK, B.W.:

Identification of a conserved microsatellite site in the porcine and bovine insulin-like growth factor-I gene 5’ flank. Anim. Genet., 23 (1992), 543-548

LIEN, S.; KARLSEN, A.; KLEMETSDAL, G.; VAGE, D.I.; OLSAKER, I.; KLUNGLAND, H.; AASLAND, M.; HERINGSTAD, B.; RUANE, J., GOMEZ-RAYA, L.:

A primary screen of the bovine genome for quantitative trait loci affecting twinning rate. Mamm. Genome, 11 (2000), 877-882

SHARIFLOU, M.R.; MORAN, C.:

Conservation within artiodactyls of an AATA interrupt in the IGF-I microsatellite for 19-35 million years. Mol. Biol. Evol., 17 (2000), 665-669

WANG, Y., PRICE, S.E., JIANG, H.:

Cloning and characterization of the bovine class 1 and class 2 insulin-like growth factor-I mRNAs. Domest. Anim. Endocrin., 25 (2003), 315-328 